\title{
EFFECT OF MILK REPLACER ON KID PRE-WEANING GROWTH, MILK PRODUCTION AND FARM PROFITABILITY OF SHAMI GOAT
}

\author{
T.M.M. Hassan ${ }^{1, ~}$, Fathy A.I. Abdelfattah ${ }^{2}$, Marwa S. Awad ${ }^{3}$ and Eman R. Kamel ${ }^{4}$
}

1- Department of Animal Production, Faculty of Agriculture, Benha University, Qalyubia 13736, Egypt, 2Department of Nutrition and Clinical Nutrition, Faculty of Veterinary Medicine, Benha University, Qalyubia 13736, Egypt, 3- Department of Food Hygiene and Control, Faculty of Veterinary Medicine, Menofia University, Shbin Elkom 32511, Egypt, 4- Department of Animal Wealth Development, Faculty of Veterinary Medicine, Benha University, Qalyubia 13736, Egypt

*Corresponding author E-mail: tamer.mohamed@fagr.bu.edu.eg

Received: 23/10/2017

\section{SUMMARY}

This study was carried out on 38 Shami female goats and 48 of their kids to investigate the effect of using milk replacer on growth performance of goat kids, goat's milk yield and composition, and economic efficiency. Two groups, (19 goats each) with their kids were used up to 12 weeks of age after kidding. The kids of first group were allowed free access to suckle their dams during the experimental period till weaning. The kids of the other group were fed milk replacer (MR) just after 3 days of receiving colostrum. A starter diet was offered after 4 weeks of age for all goat kids. Growth of kids and feed intake were measured. Milk from the dams was evaluated for yield and composition. The artificial feeding and natural suckling systems were evaluated economically to determine the farm profitability. Results showed that the MR fed kids had a better growth performance in terms of live body weight and average daily gain than the natural suckling kids. Milk production and composition were improved in MR fed kids than natural suckled counterparts. The net return (profit) was superior in MR feeding system (LE 1317.06/kid), than natural suckling (LE 419.09/kid). In this study, feeding MR to newly born goat kids instead of natural suckling had positive effects on kid growth, goat's milk yield and composition as well as the production profitability of the farm.

Keywords: Milk replacer, kid growth, profitability, Shami goats

\section{INTRODUCTION}

Goats are one of the most important economical component of animal production specially in developing countries. They live under hard environmental conditions in arid and semi-arid regions. Shami dual-purpose goats are known for their high milk production and high reproduction efficiency (Alsheikh, 2013). Milk produced till weaning including that suckled by the kids is ranged between $190 \mathrm{~kg}$ to $240 \mathrm{~kg}$, depending on the length of the suckling period (Mavrogenis et al., 2006). Kid rearing with natural suckling, where kids are kept with their dams, lasts between 45 and 75 days, and labor requirement is low, but kids may suckle more than enough and suffer from diarrhea resulting in economic loss (Keskin, 2002). Recently, milk replacer (MR) plays an important role in animal production especially for food producing animal (Keskin and Bicer, 2002). It is a very good source of liquid feed for calves, lambs and goat kids. MR manufacturing has been improved as well by formulation with ingredients that processed technically for the underdeveloped rumen of young kids (Bugti et al., 2016). This innovate technology provides highly digestible nutrients, more stable and biosecured feed ingredients into high palatability. These MR are basically formulated from cow's milk, cereals, dried whey, whey protein concentrate and vegetable fat. Goat milk production is a dynamic and growing industry that is important for the well-being and incomes for millions of people worldwide (Silanikove et al., 2010). In many developing countries, goat milk is a primary product for human consumption (Haenlein, 2006) and is considered as a valuable product for cheese manufacturing. The aim of the present study was to evaluate the use of MR in feeding Shami goat kids in terms of growth performance, milk yield and composition of dams and the profitability of farm production.

\section{MATERIALS AND METHODS}

This study was carried out with Shami (Damascus) goats reared between November 2015 to January 2016 at the experimental farm of the Faculty of Agriculture, Benha University, Egypt.

\section{Diet, experimental design and management:}

Milk replacer (MR) for kids (Chivalac) was manufactured by Nutrifeed, Netherlands and purchased from Biovet, Egypt. MR contains coconut oil and dairy products for an easy digestion and is enriched with Imagro $^{\circledR}$ (pre-and probiotics) to support immune system. The composition of MR is presented in Table1.

Diet of goats was formulated according to NRC (2007) recommendations for goats. It was composed of crushed yellow corn, wheat bran, rice bran, soybean meal, cotton seed meal, molasses, clover and wheat straw, in addition to mineral and vitamin 
supplements. A starter diet was formulated mainly from yellow corn, soybean meal and wheat bran was offered to all kids at 4 weeks of age. Feed ingredients of goat's diet and kid's starter and their chemical composition are presented in Table 2. Thirty eight female goats with their newly born kids (48) were divided into two equal groups (i.e. natural rearing and artificial rearing). Each group was composed of 14 goats with single kids and five goats with twin kids. Goats in both groups were fed the same formulated diet. Kids were ear-tagged just after birth and separated from does 3 days after birth. Within this time, they received colostrum ad libitum. For natural rearing group (control), kids were allowed to suckle their dams, while goat kids of artificial rearing group were fed on MR just after receiving colostrum. Both rearing systems were applied till weaning (12 weeks). The MR was prepared according to the maufacurer's recommendations $(180 \mathrm{~g} / \mathrm{L})$ and fed two times a day using plastic bottles with rubber nipples. The daily feed intake of MR, suckled milk and starter feed were recorded for goat kids.

Table 1. Composition of Chivalac MR dry powder used in the experiment

\begin{tabular}{lcclcc}
\hline Constituent & Unit & Qty & Constituent & Unit & Qty \\
\hline Moisture (Max) & $\%$ & 4.0 & Choline chloride & $\mathrm{mg}$ & 1000.0 \\
Crude protein (Min) & $\%$ & 22.0 & Pantothenic acid & $\mathrm{mg}$ & 40.0 \\
Crude fat (Min) & $\%$ & 18.0 & Niacin & $\mathrm{mg}$ & 50.0 \\
Carboydrates & $\%$ & 46.4 & Iron & $\mathrm{mg}$ & 110.0 \\
Minerals & $\%$ & 9.5 & Zinc & $\mathrm{mg}$ & 150.0 \\
Crude fiber & $\%$ & 0.1 & Manganese & $\mathrm{mg}$ & 70.0 \\
Lysine & $\%$ & 1.7 & Copper & $\mathrm{IU}$ & 28.0 \\
Lactose & $\%$ & 41.0 & Vitamin A & $\mathrm{IU}$ & 55000 \\
Iodine & $\mathrm{mg}$ & 1.5 & Vitamin D & $\mathrm{mg}$ & 4500 \\
Selenium & $\mathrm{mg}$ & 0.5 & Vitamin E & $\mathrm{mg}$ & 120.0 \\
Calcium & $\mathrm{g}$ & 17.0 & Vitamin C & $\mathrm{mg}$ & 6.0 \\
Phosphorus & $\mathrm{g}$ & 9.5 & Vitamin K & $\mathrm{mg}$ & 16.0 \\
Magnesium & $\mathrm{g}$ & 1.8 & Vitamin B1 & $\mathrm{mg}$ & 15.0 \\
Potassium & $\mathrm{mg}$ & 25.0 & Vitamin B2 & $\mathrm{mcg}$ & 8.0 \\
Sodium & $\mathrm{g}$ & 11.5 & Vitamin B6 & 40.0 \\
Cobalt & $\mathrm{mg}$ & 2.0 & Vitamin B12 \\
\hline
\end{tabular}

Table 2. Ingredients and chemical composition of goat's ration and kid's starter

\begin{tabular}{|c|c|c|}
\hline Ingredients (g/kg) & Goat's ration & Kid's starter \\
\hline Yellow corn & 310 & 600 \\
\hline Rice bran & - & 185 \\
\hline Wheat bran & 50 & 100 \\
\hline Wheat straw & 230 & - \\
\hline Soybean meal & 180 & 100 \\
\hline Cotton seed meal & 40 & - \\
\hline Molasses & 50 & - \\
\hline Egyptian clover & 100 & - \\
\hline Sodium chloride & 10 & 10 \\
\hline Calcium carbonate & 5 & - \\
\hline Limestone & 10 & - \\
\hline Di-calcium phosphate & 5 & - \\
\hline Ammonium chloride & 5 & \\
\hline Vitamins and minerals mixture $^{1}$ & 5 & 5 \\
\hline \multicolumn{3}{|l|}{ Chemical composition (g/kg) } \\
\hline Dry matter & 904.5 & 931.0 \\
\hline Crude protein & 151.6 & 246.1 \\
\hline Ether extract & 35.0 & 78.5 \\
\hline Nitrogen free extract (NFE) ${ }^{2}$ & 545.0 & 565.6 \\
\hline Crude fiber & 159.6 & 47.5 \\
\hline Neutral detergent fiber (NDF) & 323.5 & 214.5 \\
\hline Acid detergent fiber (ADF) & 206.7 & 77.5 \\
\hline Ash & 108.8 & 62.3 \\
\hline Metabolizable energy (ME, Mcal/kg DM) ${ }^{3}$ & 2.71 & 3.18 \\
\hline \multicolumn{3}{|c|}{$\begin{array}{l}{ }^{1} \text { Each } 1 \mathrm{~kg} \text { of vitamins and minerals mixture contain: Vit. } \mathrm{A}=4,000,000 \mathrm{IU}, \mathrm{Vit} . \mathrm{D}_{3}=833333.33 \mathrm{IU}, \mathrm{Vit} . \mathrm{E}=5,000 \mathrm{mg}, \mathrm{Zn} \\
20,000 \mathrm{mg}, \mathrm{Mg}=23333.33 \mathrm{mg}, \mathrm{Fe}=20,000 \mathrm{mg}, \mathrm{Cu}=10,000 \mathrm{mg}, \mathrm{I}=1666.66 \mathrm{mg}, \mathrm{Se}=100 \mathrm{mg}, \mathrm{Co}=333.33 \mathrm{mg} \text { and Calciu } \\
\text { carbonate up to } 1 \mathrm{~kg} .{ }^{2} \mathrm{NFE} \text { calculated as }[100-(\mathrm{CP}+\mathrm{EE}+\text { ash }+\mathrm{CF})] \text {. } \\
{ }^{3} \mathrm{ME}(\mathrm{MJ} / \mathrm{kg} \mathrm{DM})=0.012 \mathrm{CP}+0.031 \mathrm{EE}+0.005 \mathrm{CF}+0.014 \mathrm{NFE} \text { (calculated according to MAFF, 1975) and changed to } \\
\mathrm{Mcal}(* 4.184) \text {. }\end{array}$} \\
\hline
\end{tabular}


All kids were individually weighed every two weeks to the nearest 10 grams till the weaning time (12 weeks of age) to estimate average daily gain (ADG).

Goats with their kids were housed individually in hygenic metallic pens and supplied with clean water all time.

The routine vaccination program against infectious diseases and medications against internal and external parasites were applied. Milk yield of goats in both groups was measured weekly. In natural rearing group, measuring milk yield was carried out by separating kids from their dams at night, then on the next day, body weight of kids was recorded before and after suckling then goats were milked for the rest of milk if any and the total milk yield was recorded (Coombe et al., 1960). In artificial rearing group, goats were milked two times daily and the milk yield was measured.

\section{Chemical analysis:}

Samples of goat's diet, MR and kid's starter were analyzed according to A.O.A.C. (1995). Dry matter (DM) was measured using a hot air circulation oven (Heraeus Ut20, Germany) at $105{ }^{\circ} \mathrm{C}$ for 4 hours (method no. 930.15). Ash was measured using Burnout furnace Ney Vulcan D-550, USA (method no. 942.05). Crude protein (CP) was determined using Kjeltec ${ }^{\circledR}$ system 2100, FOSS-Sweden (method no. 984.13), and ether extract (EE) with Soxtec ${ }^{\circledR}$ system 2045, FOSS-Sweden (method no. 920.39). Neutral detergent fiber (NDF) and acid detergent fiber (ADF) were estimated according to the method of Van Soest et al. (1991). Organic matter (OM) was calculated from the difference between DM and ash.

Approximately $20 \mathrm{ml}$ of milk samples were prewarmed at $40{ }^{\circ} \mathrm{C}$ in water bath and thoroughly mixed in clean glass beaker. Milk analysis was carried out for total solids, fat, proteins, lactose, and non-fat solids using Milk-Scan kit (Lactostar ${ }^{\mathrm{TM}}$, Funk Gerber, Germany).

\section{Economic efficiency:}

Finance analysis was made to evaluate the production profitability of using milk replacer instead of normal suckling of goat kids. The net return (NR) was calculated according to Sankhyan (1983) from the difference between total income (TI) and total costs (TC). Total income and total costs were individually calculated for each kid. The total costs include: the feeding costs (milk, milk replacer, and ration), the labor costs (price of a farmer working hour multiplied by the number of hours employed per kid (Paez Lama et al., 2013), veterinary care costs (drugs, vaccines, and veterinary supervision). Water, electricity, equipment maintenance in addition to costs of litter and building rent value were also calculated per kid for each group. The total income included: income value from marketable milk (goat) and final live body weight (kid). All these parameters were estimated in L.E. over the course of the experiment.

\section{Statistical analysis:}

Statistical analysis was carried out using the least squares procedure for analysing data with unequal subclass number using SAS (2004). The statistical models used being as follows:

$Y_{i j k}=\mu+R_{i}+B_{j}+(R B)_{i j}+e_{i j k}($ Model 1)

Where: $Y_{i j k}=$ observation of $k$ goat milk; $\mu=$ overall mean; $R_{i}=$ fixed effect of $i^{\text {th }}$ rearing system ( $i=1,2$ while, $1=$ natural suckling and $2=$ artificial feeding); $B_{j}=$ fixed effect of $j^{\text {th }}$ birth type $(j=1,2$ while, $1=$ single and $2=$ twin $) ;(R B)_{i j}=$ the interaction between rearing system and birth type; $\mathrm{e}_{\mathrm{ijk}}=$ random error associated with the individual observation and assumed as NID $\left(0, \sigma^{2}{ }_{\mathrm{e}}\right)$.

$\mathrm{Y}_{\mathrm{ijkl}}=\mu+\mathrm{R}_{\mathrm{i}}+\mathrm{B}_{\mathrm{j}}+\mathrm{S}_{\mathrm{k}}+(\mathrm{RB})_{\mathrm{ij}}+(\mathrm{RS})_{\mathrm{ik}}+(\mathrm{BS})_{\mathrm{jk}}+$ $(\text { RBS })_{i j k}+e_{i j k l}$ (Model 2)

Where: $\mathrm{Y}_{\mathrm{ijkl}}=$ observation of $\mathrm{l}$ kid pre-weaning growth; $\mu=$ overall mean; $R_{i}=$ fixed effect of $i^{\text {th }}$ rearing system $(\mathrm{i}=1,2$ while, $1=$ natural suckling and $2=$ artificial feeding); $B_{j}=$ fixed effect of $j^{\text {th }}$ birth type ( $\mathrm{j}=1,2$ while, $1=$ single and $2=$ twin); $\mathrm{S}_{\mathrm{k}}=$ fixed effect of $j^{\text {th }}$ kid sex $(j=1,2$ while, $1=$ male and $2=$ female); $(\mathrm{RB})_{\mathrm{ij}}=$ the interaction between rearing system and birth type; $(\mathrm{RS})_{\mathrm{ik}}=$ the interaction between rearing system and kid sex; $(B S)_{j k}=$ fixed effect of the interaction between birth type and kid sex; $(\mathrm{RBS})_{\mathrm{ijk}}=$ the interaction among rearing system, birth type and kid sex; $\mathrm{e}_{\mathrm{ijk}}=$ random error associated with the individual observation and assumed NID (0, $\mathrm{o}^{2}{ }_{\mathrm{e}}$ ). Tests of significance for differences between means were carried out according to Duncan (1955).

\section{RESULTS AND DISCUSSION}

\section{Kids preweaning growth performance:}

Final live body weight (LBW) did not show significant $(\mathrm{P}<0.01)$ differences between milk replacer fed and naturally suckled kids. LBW at 28 and 56 days of age were insignificantly $(\mathrm{P}>0.05)$ higher in MR fed kids than in naturally suckled kids. The average daily gain (ADG) from 56 to 84 days of age was significantly higher $(\mathrm{P}<0.01)$ in $\mathrm{MR}$ fed kids than the milk suckling ones (168 vs $138 \mathrm{~g} /$ day). Also, ADG from birth to weaning at 84 days of age was higher $(\mathrm{P}<0.01)$ in $\mathrm{MR}$ fed kids than the milk suckling counterparts (130 vs 120 grams/day) as presented in Table 3 . The single born kids had the heaviest LBW at birth, 28 and 56 days of age. The ADG from birth to 28 days of age was higher in the single born kids than the twin born kids (122 vs 105 g). The male kids had heavier LBW than the female kids at birth, 28, 56 and 84 days of age $(\mathrm{P}<0.001)$. The ADG from birth to 28 days was higher $(\mathrm{P}<0.01)$ in the male kids than the female ones (125 vs 102g). The ADG from birth to 84 days of age was higher $(\mathrm{P}<0.05)$ in the male kids than the female kids $(129$ vs $120 \mathrm{~g})$.

In this study, the MR fed kids had better LBW and ADG than the milk suckled kids. Such 
differences might be due to the MR composition and the feed intake by kids. New technology in manufacuring MR improved its quality, taste, stability, and digestibility as well as feed additives that improve growth and feed utilization such as preand probitics in Chivalac. Most recent MR used for feeding newly born ruminants is characterized by convenience and biosecurity. They offer a variety of feed additives such as antibiotics, coccidiostats, probiotics, prebiotics, and ionophores. Also pasteurization of ingredients of MR during manufacturing can prevent diseases caused by bacteria and viruses transmitted to newly born animals from their dams in normal suckling system. Results of Ghorbani et al. (2007) showed that feeding MR was important for the development of rumen of lambs and therefore improved creep intake ensued. Similarly, Alvarez-Rodríguez et al. (2010) found that early-weaned lambs had a higher creep feed intake than suckling lambs.

Table 3. Effect of milk replacer on LBW (kg) and ADG (g) of kids from birth to 84 days of age for different rearing systems, kidding types and sexes

\begin{tabular}{|c|c|c|c|c|c|c|c|c|c|c|c|}
\hline \multirow{2}{*}{ Item } & \multicolumn{2}{|c|}{ Rearing system (RS) } & \multicolumn{2}{|c|}{ Kidding type (KT) } & \multicolumn{2}{|c|}{ Sex (S) } & \multicolumn{5}{|c|}{$\mathbf{P}$} \\
\hline & Natural & Artificial & Single & Twin & Male & Female & RS & KT & S & $\mathrm{DI}^{1}$ & $\mathrm{TI}^{2}$ \\
\hline $\begin{array}{l}\text { No. of } \\
\text { kids }\end{array}$ & 24 & 24 & 28 & 20 & 27 & 21 & & & & & \\
\hline \multicolumn{12}{|c|}{ Live weight (kg) } \\
\hline $0-28 d$ & $3.39 \pm 0.04$ & $3.50 \pm 0.1$ & $3.53 \pm 0.04^{\mathrm{a}}$ & $3.31 \pm 0.05^{\mathrm{b}}$ & $3.65 \pm 0.03^{\mathrm{a}}$ & $3.19 \pm 0.05^{b}$ & NS & $* *$ & $* * *$ & NS & NS \\
\hline $28-56 \mathrm{~d}$ & $6.4 \pm 0.2$ & $6.84 \pm 0.2$ & $6.97 \pm 0.16^{\mathrm{a}}$ & $6.27^{\mathrm{b}} \pm 0.20$ & $7.16 \pm 0.15^{\mathrm{a}}$ & $6.07 \pm 0.2^{\mathrm{b}}$ & NS & $* *$ & $* * *$ & NS & NS \\
\hline $56-84 d$ & $10.35 \pm 0.2$ & $10.47 \pm 0.3$ & $10.85 \pm 0.2^{\mathrm{a}}$ & $9.97^{\mathrm{b}} \pm 0.25$ & $11.02 \pm 0.19^{\mathrm{a}}$ & $9.80 \pm 0.25^{\mathrm{b}}$ & NS & $* *$ & $* * *$ & NS & NS \\
\hline $0-84 d$ & $14.22 \pm 0.2^{\mathrm{b}}$ & $15.19 \pm 0.3^{\mathrm{a}}$ & $15.04 \pm 0.22$ & $14.38 \pm 0.28$ & $15.34 \pm 0.22^{\mathrm{a}}$ & $14.07 \pm 0.28^{b}$ & $* *$ & NS & $* * *$ & NS & NS \\
\hline \multicolumn{12}{|c|}{ ADG (g/day) } \\
\hline $0-28 d$ & $106 \pm 5$ & $121 \pm 6$ & $122 \pm 5^{\mathrm{a}}$ & $105^{b} \pm 6$ & $125^{\mathrm{a}} \pm 5$ & $102^{\mathrm{b}} \pm 6$ & NS & $*$ & $* *$ & NS & NS \\
\hline $28-56 d$ & $141 \pm 5$ & $129 \pm 7$ & $138 \pm 5$ & $132 \pm 7$ & $138 \pm 5$ & $133 \pm 7$ & NS & NS & NS & NS & NS \\
\hline $56-84 d$ & $138 \pm 5^{b}$ & $168 \pm 6^{\mathrm{a}}$ & $149 \pm 5$ & $157 \pm 6$ & $154 \pm 5$ & $152 \pm 6$ & $* *$ & NS & NS & NS & NS \\
\hline $0-84 d$ & $120 \pm 2^{b}$ & $130 \pm 3^{a}$ & $127 \pm 2$ & $123 \pm 3$ & $129 \pm 2^{\mathrm{a}}$ & $120 \pm 3^{b}$ & $* *$ & NS & $*$ & NS & NS \\
\hline
\end{tabular}

$* \mathrm{P}<0.05 ; * * \mathrm{P}<0.01 ; * * * \mathrm{P}<0.001$; NS: not significant. $\mathrm{P}>0.05$.

${ }^{1} \mathrm{DI}=$ double interaction, ${ }^{2} \mathrm{TI}=$ triple interaction.

${ }^{\mathrm{a}, \mathrm{b}}$ Means within a row with different letters differ significantly $(\mathrm{P}<0.05)$.

$\mathrm{LBW}=$ live body weight, $\mathrm{ADG}=$ average daily gain.

This result did not agree with those of DelgadoPertínez et al. (2009a) who recorded significant differences in weight and ADG, although the milk suckling kids weighed slightly more than the MR fed kids. Paez Lama et al. (2013) found that differences between kids LBW at 45 days of age and ADG from 3 to 90 days of age were affected significantly ( $\mathrm{P}<0.05$ and $\mathrm{P}<0.01$, respectively) by Criollo kid's rearing systems. On the other hand, Keskin and Bicer (2002) recorded that the growth rate of Shami kids was not significantly affected by the kid rearing system.

Single born kids in this study had higher LBW and ADG than twin born kids. Single born kids maintained their weight superiority up to weaning and after. Results of Delgado-Pertínez et al. (2009a), Paez Lama et al. (2013), and Rojo-Rubio et al. (2015) are not in agreement with the current results regarding weaning weight and ADG. The sex of kid affected LBW and ADG. Such observation was noted by Rojo-Rubio et al. (2015) who found that male kids reached a heavier weaning weight than female kids (20 versus $18.13 \mathrm{~kg}$, respectively). The same authors noted that the higher daily weight gain at weaning for male than female kid was probably due to the male anabolic hormonal pattern which favours the growth of muscular tissues.

\section{Goat's milk yield and composition:}

Concerning daily milk yield (DMY), the female goats with MR fed kids had a higher yield than goats with natural suckling kids $(\mathrm{P}<0.01)$ (2.03 vs 1.49 $\mathrm{kg}$ /day). Goats with MR fed kids exceeded the goats with natural suckling kids in total milk yield (TMY) during 12 weeks of lactation (170.62 vs $125.88 \mathrm{~kg}$ ) (Table 4). Goats kidded twins had a significantly $(\mathrm{P}<0.05)$ higher DMY than those kidded single kids (1.99 vs $1.53 \mathrm{~kg} /$ day). Also, goats kidded twins had greater TMY $(\mathrm{P}<0.05)$ during 12 weeks of lactation than those kidded single kids (167.68 vs 128.81 kg). Several factors affecting milk yield (genetic, feeding system, stage of lactation, production system and suckling/milking frequency). These results could be attributed to the ability of goats with MR fed kids to empty the udder by complete milking twice daily, especially during the early lactation period. This might stimulate the udder to produce more milk. These results agree with those obtained by Peris et al. (1997) who found that milking Murciano-Granadina goats had higher $(\mathrm{P}<0.001)$ milk production during first seven weeks of lactation than suckling goats (91 vs 37 liters).

Otherwise, Delgado-Pertínez et al. (2009a) with Payoya dairy goats, found that the rearing system affected the TMY from birth to the $30^{\text {th }}$ week of lactation, manifesting higher milk yields from the natural suckling system. Other studies using the same 
breed revealed that kid rearing system did not affect the milk yield (Keskin, 2002; Keskin and Bicer, 2002). The greater milk yield by goats which kidded twin kids is in accordance with previous findings by Carnicella et al.(2008) which showed an increase of $27 \%$ in milk with single fetus and $47 \%$ with twin fetuses due to systemic effects of increased secretion of placental lactogen. Rojo-Rubio et al. (2015) attributed such effect to the stimulation exerted by more than a kid goat suckling on the udder; leading to an increase in milk production, in addition to hormonal effects during pregnancy.

The pattern of milk quality in terms of its chemical composition (fat, protein, total solids and lactose) is presented in Table 5. Generally, fat, protein and total solids during the first 4 weeks of lactation were insignificantly higher $(\mathrm{P}<0.05)$ in milk from goats with MR fed kids than that of goats with natural suckling kids (4.30, 3.30 and $13.15 \%$ vs 5.23 , 3.58 and $13.90 \%$, respectively). However, lactose and non-fat solids showed an increase trend.

Table 4. Least-squares means $( \pm \mathrm{SE})$ of milk yield from Shami goats $(\mathrm{kg})$ during the experimental period.

\begin{tabular}{|c|c|c|c|c|c|c|c|}
\hline \multirow{2}{*}{ Item } & \multicolumn{2}{|c|}{ Rearing system (RS) } & \multicolumn{2}{|c|}{ Kidding type (KT) } & \multicolumn{3}{|c|}{$\mathbf{P}$} \\
\hline & Natural & Artificial & Single & Twin & RS & KT & $\mathrm{RS} \times \mathrm{KT}$ \\
\hline Number of goats & 19 & 19 & 28 & 10 & & & \\
\hline \multicolumn{8}{|c|}{ Weeks 1-4 } \\
\hline Daily yield & $1.6 \pm 0.2$ & $1.7 \pm 0.2$ & $1.4 \pm 0.1^{\mathrm{b}}$ & $1.9 \pm 0.2^{\mathrm{a}}$ & NS & $*$ & NS \\
\hline Total yield & $43.9 \pm 4.9$ & $47.4 \pm 4.8$ & $39.0 \pm 4.1^{\mathrm{b}}$ & $52.4 \pm 5.7^{\mathrm{a}}$ & NS & $*$ & NS \\
\hline \multicolumn{8}{|c|}{ Weeks 5-8 } \\
\hline Daily yield & $1.8 \pm 0.2$ & $2.1 \pm 0.1$ & $1.6 \pm 0.1^{\mathrm{b}}$ & $2.2 \pm 0.2^{\mathrm{a}}$ & NS & $*$ & NS \\
\hline Total yield & $49.6 \pm 4.3$ & $57.5 \pm 4.2$ & $46.2 \pm 3.6^{\mathrm{b}}$ & $60.9 \pm 4.9^{\mathrm{a}}$ & NS & $*$ & NS \\
\hline \multicolumn{8}{|c|}{ Weeks 9-12 } \\
\hline Daily yield & $1.2 \pm 0.1^{\mathrm{b}}$ & $1.5 \pm 0.1^{\mathrm{a}}$ & $1.1 \pm 0.1^{\mathrm{b}}$ & $1.5 \pm 0.1^{\mathrm{a}}$ & $*$ & $*$ & NS \\
\hline Total yield & $32.5 \pm 3.1^{\mathrm{b}}$ & $41.2 \pm 3.0^{\mathrm{a}}$ & $31.5 \pm 2.6^{\mathrm{b}}$ & $42.2 \pm 3.6^{\mathrm{a}}$ & $*$ & $*$ & NS \\
\hline \multicolumn{8}{|c|}{ Weeks 1-12 } \\
\hline Daily yield & $1.5 \pm 0.14^{\mathrm{b}}$ & $2.0 \pm 0.1^{\mathrm{a}}$ & $1.5 \pm 0.12^{\mathrm{b}}$ & $1.99 \pm 0.2^{\mathrm{a}}$ & $* *$ & $*$ & NS \\
\hline Total yield & $125.9 \pm 12.3^{b}$ & $170.6 \pm 12.0^{\mathrm{a}}$ & $128.8 \pm 10.1^{\mathrm{b}}$ & $167.7 \pm 13.9^{\mathrm{a}}$ & $* *$ & $*$ & NS \\
\hline
\end{tabular}

Table 5. Least-squares means $( \pm \mathrm{SE})$ of milk composition from Shami goats $(\mathrm{kg})$ during the experimental period

\begin{tabular}{|c|c|c|c|c|c|c|c|}
\hline \multirow{2}{*}{ Item } & \multicolumn{2}{|c|}{ Rearing system (RS) } & \multicolumn{2}{|c|}{ Kidding type (KT) } & \multicolumn{3}{|c|}{$\mathbf{P}$} \\
\hline & Natural & Artificial & Single & Twin & $\mathrm{RS}$ & KT & $\mathrm{RS} \times \mathrm{KT}$ \\
\hline Number of goats & 19 & 19 & 28 & 10 & & & \\
\hline \multicolumn{8}{|c|}{ Weeks 1-4 } \\
\hline Total solids & $13.15 \pm 0.2$ & $13.90 \pm 0.2 \overline{9}$ & $13.97 \pm 0.2$ & $13.07 \pm 0.29$ & NS & NS & NS \\
\hline Fat & $4.30 \pm 0.4$ & $5.23 \pm 0.47$ & $5.51 \pm 0.4$ & $4.02 \pm 0.47$ & NS & NS & NS \\
\hline Protein & $3.30 \pm 0.2$ & $3.58 \pm 0.2$ & $3.65 \pm 0.2$ & $3.23 \pm 0.24$ & NS & NS & NS \\
\hline Lactose & $4.26 \pm 0.26$ & $4.17 \pm 0.3$ & $3.62 \pm 0.26^{\mathrm{b}}$ & $4.81 \pm 0.3^{\mathrm{a}}$ & NS & $*$ & NS \\
\hline Non-fat solids & $8.85 \pm 0.19$ & $8.66 \pm 0.2$ & $8.46 \pm 0.19$ & $8.05 \pm 0.2$ & NS & NS & NS \\
\hline \multicolumn{8}{|c|}{ Weeks 5-8 } \\
\hline Total solids & $12.87 \pm 0.2$ & $12.84 \pm 0.1 \overline{8}$ & $13.16 \pm 0.18$ & $12.55 \pm 0.2$ & NS & NS & NS \\
\hline Fat & $3.55 \pm 0.35$ & $3.63 \pm 0.29$ & $4.01 \pm 0.29$ & $3.17 \pm 0.35$ & NS & NS & NS \\
\hline Protein & $3.34 \pm 0.2$ & $2.98 \pm 0.18$ & $3.25 \pm 0.18$ & $3.07 \pm 0.2$ & NS & NS & NS \\
\hline Lactose & $4.79 \pm 0.17$ & $4.24 \pm 0.15$ & $4.38 \pm 0.15$ & $4.66 \pm 0.17$ & NS & NS & NS \\
\hline Non-fat solids & $9.32 \pm 0.1$ & $9.21 \pm 0.1$ & $9.15 \pm 0.1$ & $9.38 \pm 0.1$ & NS & NS & NS \\
\hline \multicolumn{8}{|c|}{ Weeks 9-12 } \\
\hline Total solids & $13.01 \pm 0.1^{\mathrm{a}}$ & $12.58 \pm 0.09^{b}$ & $12.84 \pm 0.08$ & $12.75 \pm 0.1$ & $*$ & NS & NS \\
\hline Fat & $3.57 \pm 0.2$ & $3.43 \pm 0.2$ & $3.50 \pm 0.2$ & $3.50 \pm 0.26$ & NS & NS & NS \\
\hline Protein & $3.05 \pm 0.1$ & $2.69 \pm 0.1$ & $2.86 \pm 0.1$ & $2.87 \pm 0.1$ & NS & NS & NS \\
\hline Lactose & $4.12 \pm 0.2$ & $4.67 \pm 0.2$ & $3.86 \pm 0.2$ & $3.93 \pm 0.27$ & NS & NS & NS \\
\hline Non-fat solids & $9.43 \pm 0.2$ & $9.15 \pm .2$ & $9.34 \pm 0.19$ & $9.24 \pm 0.2$ & NS & NS & NS \\
\hline \multicolumn{8}{|c|}{ Weeks 1-12 } \\
\hline Total solids & $12.98 \pm 0.17$ & $13.05 \pm 0 . \overline{16}$ & $13.3 \pm 0.15^{\mathrm{a}}$ & $12.72 \pm 0.18^{\mathrm{b}}$ & NS & $*$ & NS \\
\hline Fat & $3.76 \pm 0.28$ & $4.03 \pm 0.27$ & $4.29 \pm 25$ & $3.49 \pm 0.30$ & NS & NS & NS \\
\hline Protein & $3.20 \pm 0.13$ & $3.05 \pm 0.12$ & $3.23 \pm 0.11$ & $3.01 \pm 0.14$ & NS & NS & NS \\
\hline Lactose & $4.40 \pm 0.16$ & $3.98 \pm 0.15$ & $3.95 \pm 0.14^{\mathrm{b}}$ & $4.44 \pm 0.17^{\mathrm{a}}$ & NS & $*$ & NS \\
\hline Non-fat solids & $9.21 \pm 0.13$ & $9.02 \pm 0.13$ & $9.01 \pm 0.12$ & $9.22 \pm 0.15$ & NS & NS & NS \\
\hline
\end{tabular}


The twin-kidded goats had a significantly $(\mathrm{P}<0.05)$ higher lactose during the first 4 weeks of lactation than the single-kidded goats (4.81 vs $3.62 \%)$. During the 12 weeks of lactation, there were significant $(\mathrm{P}<0.05)$ effects on contents of total solids and lactose. Total solids increased in the singlekidded goat than the twin-kidded ones (13.31vs $12.72 \%)$. On the other hand, lactose was greater in the twin-kidded goats than the single-kidded ones (4.44 vs 3.95\%). There were no significant differences regarding milk fat, non-fat solids and protein contents. Results in this study showed a decrease in milk fat, total solids and protein in the early stage followed by an increase in later stage of the study. These results were consistent with findings by Prasad et al. (2005). Such variation could be explained by the negative correlation between milk yield with fat and total solid content (Merkhan, 2011). Effect of birth type was only significant regarding contents of total solids and lactose where the goats with single births produced higher total solids compared with those with twins which produce milk with high lactose contents. These results are in contrast with those of the study by Delgado-Pertínez et al. (2009a) who obtained non-significant effect of birth type on lactose contents.

\section{Economic efficiency:}

Data of costs, income and net return are shown in Table 6. The total costs (TC) of kids raised on suckling goat milk were significantly higher $(P<0.05)$ than TC of kids raised on MR. For the natural rearing system, total costs included the cost of suckled milk (LE 419.60/kid), cost of feed intake (LE32.19/kid), labor cost (LE 26/kid), building rent value (LE $13.20 /$ kid), water and electricity (LE 1.50/kid), and total veterinary management (LE 9/kid). Concerning total costs of feeding MR system, it included the cost of MR (LE 245.75/kid), suckling equipment cost (LE 10/kid), feed intake cost (LE 35.59/kid), labor cost (LE 55/kid), building rent value (LE 13.20/kid), water and electricity (LE 1.70/kid), and total veterinary management (LE 9/kid).

Table 6. The effect of feeding milk replacer on farm production profitability

\begin{tabular}{lcc}
\hline \multirow{2}{*}{ Item } & \multicolumn{2}{c}{ Rearing system } \\
\cline { 2 - 3 } & Natural & Artificial \\
\hline Marketable milk yield (kg/goat) & $60.67 \pm 10.87$ & $163.90 \pm 8.99$ \\
Income from marketable milk (L.E./goat) & $424.68 \pm 76.06$ & $1147.30 \pm 62.90$ \\
Live weight gain (kg/kid) & $11.02 \pm 0.23$ & $12.0 \pm 0.19$ \\
Income from live weight (L.E. /kid) & $495.90 \pm 11.96$ & $540.00 \pm 9.84$ \\
Milk replacer cost (L.E. /kid) & - & $245.75 \pm 2.66$ \\
Suckled milk cost (L.E. /kid) & $419.60 \pm 50.17$ & - \\
Feed intake (kg/kid) & $9.20 \pm 0.14$ & $10.17 \pm 0.21$ \\
Feed cost (L.E./kid) & $32.19 \pm 0.49$ & $35.59 \pm 0.73$ \\
Labor cost (L.E./kid) & 26 & 55 \\
Suckling equipment cost (L.E. /kid) & - & 10 \\
Building rent value (L.E. /kid) & 13.20 & 13.20 \\
Electricity and water cost (L.E. /kid) & 1.50 & 1.70 \\
Total management cost (L.E. /kid) & 9 & 9 \\
Total costs (L.E. /kid) & $501.49^{\mathrm{a}} \pm 50.37$ & $370.24^{\mathrm{b}} \pm 5.52$ \\
Total income (L.E. /kid) & $920.58^{\mathrm{b}} \pm 80.66$ & $1687.30^{\mathrm{a}} \pm 65.38$ \\
Net return (L.E. /kid) & $419.09^{\mathrm{b}} \pm 75.07$ & $1317.06^{\mathrm{a}} \pm 63.79$ \\
\hline
\end{tabular}

Price of goat milk: 7 (L.E./Kg); Price of milk replacer: 2.5 (L.E./Kg);

Price of live weight of kid: 45 (L.E./Kg).

${ }^{\mathrm{a}, \mathrm{b}}$ Means within a row with different letters differ significantly $(\mathrm{P}<0.05)$.

These differences in the total costs were due to the feed cost that comprised 60 to $70 \%$ of total production costs. In the present study, the suckled milk cost in natural suckling system was significantly higher than MR intake cost, this could be due to difference in market prices of goat milk and MR, goat milk was between 30 and $40 \%$ more expensive than MR. These results are in agreement with those reported by Perez et al. (2001) and Delgado-Pertínez et al. (2009a).

Labor costs were significantly $(P<0.05)$ higher in MR feeding system than those of natural suckling system. These results agree with those of DelgadoPertínez et al. (2009a) who found that MR feeding system required twice more labor than that with the natural suckling system. Contrary to the present results, other authors found that total operating costs of kids raised on MR were significantly higher than the costs of kids raised on goat milk. Galina et al. (1995) found that feeding MR was more expensive than feeding on goat milk, whereas Delgado-Pertínez et al. (2009b) found no major differences between natural and artificial rearing. The total income obtained from marketable milk sales and final live weight price were significantly $(\mathrm{P}<0.05)$ higher for the MR system (LE 1687.30/kid) than natural suckling (LE 920.58/kid). Net return was significantly higher $(P<0.05)$ in the MR system (LE $1317.06 / \mathrm{kid})$ than that for natural suckling system (LE 419.09/kid). Financial analysis of the kid rearing 
systems showed that MR feeding system earned about LE 897.97/goat more profit than the natural suckling system. This may be due to that MR feeding system increased marketable milk yield by about $103.23 \mathrm{~kg} /$ goat more than the natural suckling system during the experimental period. In addition, kids in the MR feeding system gained $1 \mathrm{~kg} / \mathrm{kid}$ extra live weight.

Therefore, results of the present study showed that providing MR instead of goat milk for rearing Shami goat kids increases farm profitability.

\section{CONCLUSION}

Raising goat kids on MR just after colostrum period till weaning had positive effects on kid preweaning growth, dam's milk yield and composition and production profitability. Recent manufacuring technology provides high quality and biosecured MR for newly born animals. Therefore, dairy goat producers should rear their kids by such system for more milk yield, kid pre-weaning growth and more production profits.

\section{ACKNOWLEDGEMENT}

The authors are grateful to the staff of the Animal Farm, Faculty of Agriculture, Benha University (www.bu.edu.eg) for their technical assistance. Special thanks were to Scientific Research Fund, Benha University, Egypt for their financial support.

\section{REFERENCES}

A.O.A.C., 1995. Official Methods of Analysis, 16th ed. Association of Official Analytical Chemists (A.O.A.C), Arlington, VA, USA.

Alsheikh, S.M., 2013. Influence of age and live body weight on daily milk yield of Zaraibi and Shami goats in Sinai, Egypt. Annals of Agricultural Science. 58(1):1-3.

Alvarez-Rodríguez, J.; A. Sanz; R. Ripoll-Bosch and M. Joy, 2010. Do alfalfa grazing and lactation length affect the digestive tract fill of light lambs? Small Ruminant Res. 94, 109-116.

Bugti, A.G.; H.A. Kaleri; S. Zaman; M.A. liShah; A.H. Kaleri; R.R. Kaleri; I.K. Baloch, 2016. Effect of milk replacer on the growth of goat kids. Journal of Agriculture Biotecnology, 1 (1): 22-25.

Carnicella, D.; M. Dario; M.C.C. Ayres; V. Laudadio and C. Dario, 2008. The effect of diet, parity, year and number of kids on milk yield and milk composition in Maltese goat. Small rumin. Res. 77, 71-74.

Coombe, J.B.; I.D. Wardrop and D.E.Tribe, 1960. A study of milk production of the grazing ewe, with emphasis on the experimental technique employed. J. Agric. Sci. 54, 353-359.

Delgado-Pertínez, M.; J.L. Guzmán-Guerrero; F.P. Caravaca; J.M. Castel; F.A. Ruiz; P. GonzálezRedondo and M.J. Alcalde, 2009a. Effect of artificial vs. natural rearing on milk yield, kid growth and cost in Payoya autochthonous dairy goats. Small rumin. Res. 84, 108-115.

Delgado-Pertínez, M.; J.L. Guzmán-Guerrero; Y. Mena; J.M. Castel; P. González-Redondo and F.P. Caravaca, 2009b. Influence of kid rearing systems on milk yield, kid growth and cost of Florida dairy goats. Small rumin. Res. 81, 105111.

Duncan, D.B., 1955. Multiple ranges and multiple Ftest. Biometrics. 11, 1-42.

Galina, M.A.; M. Palma; D. Pacheco and R. Morales, 1995. Effect of goat milk, cow milk, cow milk replacer and partial substitution of the replacer mixture with whey on artificial feeding of female kids. Small rumin. Res. 17, 153-158.

Ghorbani, G.R.;R. Kowsar; M. Alikhani and A. Nikkhah, 2007. Soymilk as a novel milk replacer to stimulate early calf starter intake and reduce weaning age and costs. J. Dairy Sci. 90, 56925697.

Haenlein, G.F.W., 2006. About the evaluation of goat and sheep milk production. Small rumin. Res. 68, 3-6.

Keskin, M., 2002. Effect of rearing systems on kid performance, lactation traits and profitability of Shami (Damascus) Goats. J. Appl. Anim. Res 22, 267-271.

Keskin, M. and O. Bicer, 2002. Effects of milk replacer on kid growth and farm profitability in the Shami goat. Turk. J. Vet. Anim. Sci. 26, 1133-1136.

MAFF, 1975. Energy allowances and feeding systems of Ruminants. Ministry of Agriculture Fisheries and Food. Technical Bulletin 33. London UK.

Mavrogenis, A.P.; N.Y. Antoniades and R.W. Hooper, 2006. The Damascus (Shami) goat of Cyprus. Anim. genetic Resources Information 38, 57-65.

Merkhan, K.Y., 2011. A study on milk yield, compositional and udder morphology characteristics in the local and Meriz goats raised in commercial farms. M. Sc. Thesis, Fac. Agric. and Forestry, University of Duhok.

N.R.C., 2007. Nutrient Requirements of Small Ruminant. National Academy Press, Washington, DC.

Paez Lama, S.; V. Egea; D. Grilli; M. Fucili; L. Allegretti and J.C. Guevara, 2013. Growth and economic performance of kid production under different rearing systems and slaughter ages in arid areas of Argentina. Small rumin. Res. 110, 914.

Perez, P.; M. Maino; M.S. Morales and A. Soto, 2001. Effect of goat milk and milk substitutes and sex on productive parameters and carcass composition of Creole kids. Small rumin. Res. 42, 87-94.

Peris, S.; G. Caja; X. Such; R. Casals; A. Ferret and C. Torre, 1997. Influence of Kid Rearing Systems on Milk Composition and Yield of Murciano- 
Granadina Dairy Goats. J. Dairy Sci. 80, 32493255.

Prasad, H.; H.A. Tewari and O.P.S. Sengar, 2005. Milk yield and composition of the Beetal breed and their crosses with Jamunapari, Barbari and Black Bengal breeds of goat. Small rumin. Res. 58 (2), 195-199.

Rojo-Rubio, R.; A.E. Kholif; A.Z.M. Salem; G.D. Mendoza; M.M.M.Y. Elghandour; J.F. VazquezArmijo and H. Lee-Rangel, 2015. Lactation curves and body weight changes of Alpine, Saanen and Anglo-Nubian goats as well as preweaning growth of their kids. J. of Applied Anim. $2,1-7$.
Sankhyan, L.P., 1983. Introduction to farm management. Tata MC-Grow Hill Publishing Company Limited, New Delhi.

S.A.S., 2004. SAS Procedure Guide” version 9 Ed”. SAS Institute Inc., Cary, NS, USA.

Silanikove, N.; G. Leitner; U. Merin and C.G. Prosser, 2010. Recent advances in exploiting goat's milk: Quality, safety and production aspect. Small rumin. Res. 89, 110-124.

Van Soest, P.J.; J.B. Robertson and B.A. Lewis, 1991. Methods for dietary fiber, neutral detergent fiber and non-starch polysaccharides in relation to animal nutrition. J. Dairy Sci. 74, 3583-3597.

\footnotetext{
تأثير بليل اللبن على نمو صغار الماعز قبل الفطام وانتاج اللبن والعائد للمزرعة فى الماعز الثامى تامر مسعد محمد محمد حسن' و فتحى عطية إسماعيل عبد الفتاحَّ و مروة عوض معوض سعدَّ و ايمان رمضان كامل؛

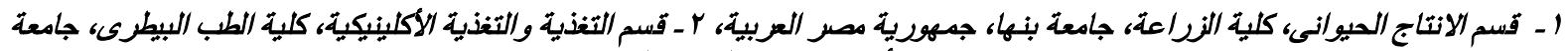

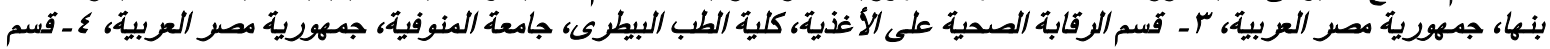

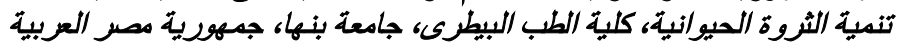

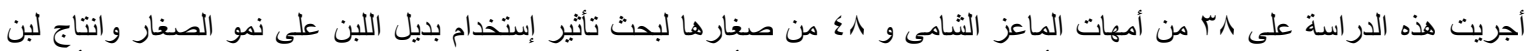

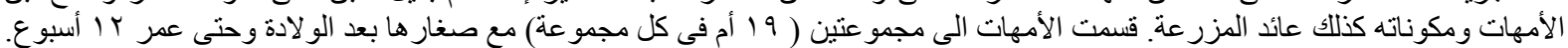

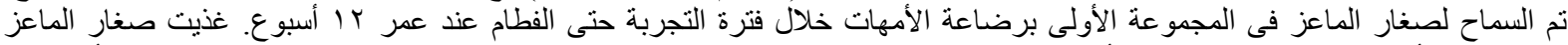

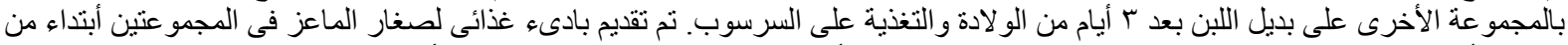

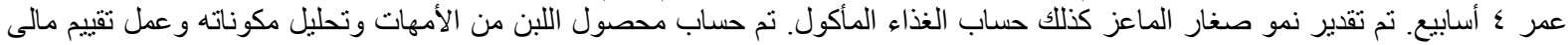

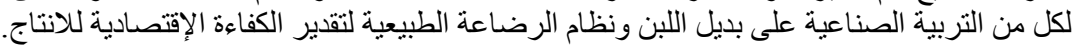

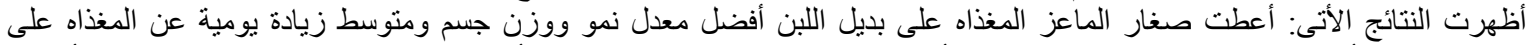

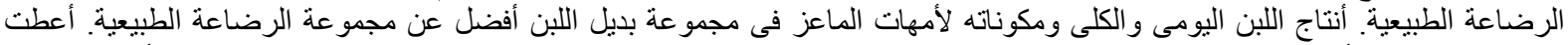

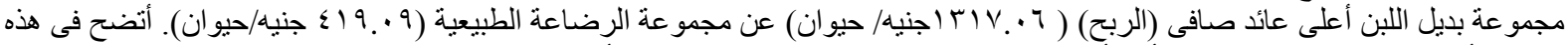

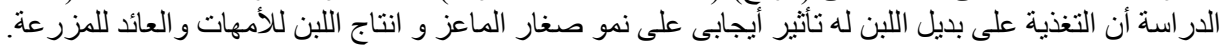

